\title{
O PENSAMENTO POLÍTICO E A REDEMOCRATIZAÇÃO DO BRASIL*
}

Marilena Chauí e Marco Aurélio Nogueira

Cicero Araujo: Quero agradecer a presença do público e também registrar a presença do presidente do Cedec, Paulo Eduardo Elias. Além de dirigir o Departamento de Ciência Política desta Faculdade, sou editor de Lua Nova, revista patrocinada pelo Cedec, e a sua diretoria encarregou-me de montar e coordenar esse debate. Antes de passar a palavra aos expositores, gostaria de fazer uma nota introdutória para explicar as pretensões dessa conversa.

O Cedec nasceu em maio de 1976, de uma cooperação com diversos intelectuais, alguns externos à academia, mas a maioria vinda de uma atuação profissional de docência e pesquisa nas universidades públicas paulistas. Isso, numa época em que o ambiente ideológico dessas universidades não era muito propício para o tipo de inquietação que esses docentes viviam. E assim surgiu o Cedec.

* Seminário realizado na Faculdade de Filosofia, Letras e Ciências Humanas da USP, em 26.04.2006. 
1976 é um momento particularmente interessante da conjuntura nacional porque a ditadura dava os primeiro sinais de fraqueza; certamente não eram seus estertores, mas eram, sim, de debilitamento. Dois anos antes, em 1974, ela havia sido derrotada nas eleições para o Senado nos principais Estados do país, inclusive São Paulo e, no ano seguinte, foi malsucedida no esforço de abafar um protesto contra o assassinato de Vladimir Herzog, um jornalista da TV Cultura, que fora "suicidado" nos porões do Doi-Codi. Ainda que não esgotada, as dificuldades da ditadura já davam ensejo a expectativas sobre o que poderia acontecer: se ela caísse mais à frente, ou caso se desmantelasse ou qualquer coisa do tipo, o que viria no seu lugar? Isso instigava a reflexão de todos e também dos colegas do Cedec. Porém, mais do que se perguntar sobre o quê viria no lugar dela, a pergunta era pelo quê se deveria batalhar, o que deveria ser colocado no lugar da ditadura.

Por exemplo, alguns inquiriam sobre a viabilidade de fazer crescer no Brasil algo parecido ao que ocorria na Europa Ocidental ou na América do Norte, isto é, uma democracia de partidos fortes, tradicionais, inclusive socialistas. É bom registrar que, na época, grande parte dos pesquisadores do Cedec se considerava, vagamente ou com alguma variação, socialista, gente que batalhava por essa ou aquela forma de socialismo. Outros achavam que o Brasil bem poderia retomar a trilha abandonada em 1964, a democracia que emergiu da Constituinte de 1946. E, ainda, havia outros, talvez a maioria dos cedequianos, que apostavam num novo tipo de democracia no Brasil, que não fosse uma imitação da européia e daquela da América do Norte, mas, especialmente, não fosse uma repe- 
tição do regime pré-64. Em resumo, uma democracia sem as marcas do getulismo da democracia anterior; aliás, quando se falava em getulismo, falava-se (e ainda se fala) em "populismo".

Apesar de toda essa indeterminação sobre o futuro, uma coisa era considerada mais ou menos certa: a ditadura não cairia com a entrada triunfal de um grupo de guerrilheiros nas portas das cidades, apoiados em massa por camponeses, escondidos nas montanhas, nas florestas ou no interior profundo do país. Lutas nesse sentido haviam sido feitas, mas a ditadura conseguiu desmantelá-las, uma a uma. Também já não se considerava tão a sério a possibilidade de uma insurreição armada, popular, nas grandes cidades, que afinal convergisse para algum palácio de governo abandonado ou à disposição. Aliás, era muito comum, na época, os colegas do Cedec terminarem suas reflexões com a seguinte frase: "Ninguém aqui vai tomar de assalto o Palácio de Inverno!". É claro que essa frase tinha a ver com um debate que ocorria muito longe do Brasil, na Europa Ocidental, aquele lugarzinho do planeta espremido entre o Atlântico Norte, isto é, os Estados Unidos e o rio Elba, isto é, o bloco soviético. "Espremida" é uma metáfora para a esquerda européia, prensada entre um liberalismo chuvoso, garoento, no Atlântico, e um socialismo frio, cinzento, de inverno mesmo, no Oriente. Aquela esquerda, provavelmente, não queria nenhum dos dois, mas conversava com ambos e acabou dando guarida a um debate dos mais frutíferos da época, sobre o qual o professor Marco Aurélio Nogueira talvez possa nos dar mais detalhes depois.

Enfim, entre o que poderia acontecer e o que estava acontecendo havia uma brecha, um intervalo a 
ser ocupado pelo pensamento, com suas ansiedades, angústias e esperanças. Evidentemente, esse intervalo sempre vai existir em todos nós, mas aquele era um intervalo especial, principalmente para aqueles que se colocavam contra a ditadura. Porque aqueles que viviam em conforto com a ditadura, beneficiando-se da sua repressão e da sua violência, tinham já um preço a pagar: o pensamento amortecido; enquanto os que viviam sob o tacão da ditadura, sofrendo sua truculência, pelo menos tinham esse recurso, para não dizer esse último recurso: a força do pensamento. Enquanto a ditadura fazia o seu trabalho com barulho, e, muitas vezes, o fazia com enorme brutalidade, o pensamento também fazia o seu, quase silencioso, quase invisível, mas sutil.

Quando fazia essas anotações, até me surpreendi ao usar essa expressão, "força do pensamento". E lembrei-me justamente de que, nessa época - eu ainda era um moleque, adolescente -, estava muito preocupado com a tal força do pensamento, embora não estivesse nem um pouco preocupado com ditadura ou democracia. Na época, se não me engano, circulava pelos jornais e televisão um sujeito que dizia ter a "força do pensamento", por exemplo, para entortar garfos ou mover coisas. E imaginava se a tal "força do pensamento" poderia, eventualmente, ajudar o meu time a ganhar o campeonato daquele ano... porque o Corinthians simplesmente não ganhava campeonato havia quase vinte anos! Hoje estou (mais ou menos) convencido de que não dá para entortar garfo com o pensamento, muito menos ajudar o Corinthians a ganhar campeonato. Por outro lado, olhando em retrospecto, fico convencido de que a "força do pensamento", no sentido menos literal de que 
estava falando antes, especialmente o pensamento político - e se olharmos o pensamento como um empreendimento coletivo - trabalhou muito bem durante esse intervalo histórico. E sou capaz de assegurar-lhes que alguma coisa ele é capaz de entortar, ou desentortar!

De certo modo, é sobre isso que vamos conversar aqui. Peço aos expositores que fiquem inteiramente à vontade para abordarem essas e outras questões da maneira que acharem apropriada. Passo então a palavra à professora Marilena Chauí.

Marilena Chauí: Na hora em que o Cícero me fez o convite, aceitei e, ao voltar para casa, me dei conta de que estou começando a ocupar um lugar a respeito do qual o Antonio Candido falou muito. Porque ele ocupou esse lugar - e espero que ele o ocupe durante muito tempo; talvez ele e o Mário Pedrosa foram os primeiros a ocupá-lo, que é o da chamada "testemunha ocular dos fatos". Agora, cada vez que se comemoram 25 anos disso, ou 30 daquilo, não preciso imaginar o que estava acontecendo: eu estava lá, participando da criação daquilo que se comemora. Então, quando me dispus a falar, pensei que talvez o mais interessante, levando em conta, sobretudo, um público muito jovem, seria fazer um relato dessa história, do que se passava, de quais eram os temas em discussão em 1976 e, depois, como é que o Cedec nasceu e como ele funcionava nessa fase inicial.

O Cicero acaba de lembrar a vocês que 1976 é o momento em que, depois dos acontecimentos mencionados por ele, em 1974, a derrota da Arena pelo "Mandabrasa" (era assim que os bóias-frias chamavam o MDB), e depois, em 1975, o assassinato do Vla- 
dimir, surge uma reflexão sobre alguns temas. Essa reflexão já existia, mas ela se aguça em 1976 e toma como parâmetro a questão de se estávamos ou não no final da ditadura.

Dividi a minha exposição em duas partes: a primeira é o levantamento daquilo que, penso, eram os principais temas do pensamento político; a segunda, uma apresentação muito breve do nascimento do Cedec. Começo, então, destacando (entre muitos outros) quatro temas, que eram muito discutidos na época e muito discutidos no Cedec, quando ele surgiu. Vou mencioná-los não só pela relevância que têm no período, mas também pela relevância que têm na fundação do Cedec: a crise de legitimidade da ditadura (ou, como se dizia, do "sistema”), o autoritarismo na América Latina, a relação entre democracia e socialismo, a crítica da ideologia. Quanto ao nascimento do Cedec, irei enfatizar o que julgo sua principal e mais original contribuição: a afirmação da existência da sociedade brasileira (não se surpreendam!) e o papel político dos movimentos sociais.

\section{Os temas em debate}

\section{A crise de legitimidade do "sistema"}

No vocabulário político daquela época, distinguia-se o "sistema" e o "regime": este era o governo; aquele, a estrutura do poder do Estado montada pela ditadura, cujo fundamento era a ideologia da segurança nacional (ou seja, o combate ao "inimigo interno", portanto, a repressão ou o terror de Estado). A questão que se discutia, a partir, sobretudo, de 1974, era se havia uma crise de legitimidade do "sistema" e se essa crise abriria um vazio de poder. Essa discussão era inseparável da idéia desenvolvida pelo general 
Golbery do Couto e Silva e posta em prática pelo general-presidente Ernesto Geisel, da "abertura democrática" ou, na linguagem de Golbery, a "distensão lenta, gradual e segura". A palavra "distensão" não veio por acaso. O general Golbery escreveu, entre várias obras, uma sobre a questão da segurança nacional, na qual desenvolvia a tese de que os Estados, as nações em geral e o Brasil são como um organismo que opera à maneira do coração, com sístoles e diástoles. E é essa concepção naturalista e organicista da sociedade e do Estado que aparece na idéia da "abertura democrática" como "distensão". Com freqüência, o general Golbery referia-se a ela dizendo: "estamos na diástole". Essa distensão, para que fosse lenta e segura - isto, para que os militares e o capital não perdessem o controle do poder de Estado -, fez com que o "sistema" produzisse algo que ficou conhecido entre nós como o "pacote de abril”. Este foi apresentado como um conjunto de "salvaguardas", que permitiriam a manutenção dos ideais de 1964: a ordem (contra a luta de classes e as esquerdas), o desenvolvimento (a definição da economia pelos interesses do capital), o progresso (o chamado "Brasil Grande") e, surpreendentemente, a democracia (entendida como regime constitucional e representativo).

Vou mencionar algumas coisas contidas no Pacote de Abril. Como o MDB derrotou o partido do governo, a Arena, era preciso encontrar uma maneira de esta se tornar imbatível. Para isso, o general Golbery realizou duas grandes proezas: a primeira foi a mudança institucional do território brasileiro. Ele elevou à condição de estado todos os territórios, e dividiu o estado do Mato Grosso e o estado de Goiás, criando o Mato Grosso do Sul e o Tocantins, 
instituindo, em todos esses novos estados, condições fortíssimas para o poderio local da Arena e permitindo, pela aberração da forma da representação no Brasil, a hiper-representação de certos estados e a sub-representação de outros. Ele criou também uma figura formidável, os senadores como os "homens bons" da República, escolhidos pelos generais (e não eleitos por sufrágio universal), com mandato vitalício. Na época, passava um seriado na televisão chamado "O Homem de Seis Milhões de Dólares". Era um astronauta cuja nave caía e ele se espatifava inteiro; tendo, porém, sobrado uns pedaços do corpo, cientistas o reconstituíam; era um autômato, um "cyborg" ou um "biônico". A população não teve dúvidas: os senadores vitalícios passaram a ser chamados de "senadores biônicos".

Houve também a reformulação da ideologia da segurança nacional, por meio da famosa Lei 477, e o controle sobre as duas formas de oposição, isto é, a oposição institucional, realizada nos parlamentos pelo MDB (e que se caracterizava freqüentemente por grandes lances dramáticos, vindos particularmente de Teotônio Vilela e Ulysses Guimarães), e a oposição que se realizava no interior da sociedade pela CNBB, OAB, ABI, DCEs livres e oposições sindicais. A principal característica dessa oposição que se realizava no interior da sociedade é que ela conseguia mobilizações pontuais para determinadas questões que, além de serem pontuais, eram efêmeras e, na verdade, mobilizavam pouco a sociedade como um todo. A participação maior era das categorias profissionais (sindicatos e associações), dos estudantes e do grupo que estava diretamente interessado no assunto daquela mobilização. As reivindicações eram limitadas e a discussão 
em torno da abertura democrática e do vazio do poder, curiosamente, não incluía uma questão que era essencial - porque foi isso que garantiu, que deu sustentáculo à ditadura - e que no Brasil era novíssima, ou seja, as multinacionais. Não sei se estou falando de fantasmas, não sei se ainda existem as multinacionais, isso é outra coisa, mas elas estavam lá e exerciam um domínio total sobre a economia e sobre a classe operária, por meio do controle industrial, fabril. Elas financiavam todas as operações da "segurança nacional", juntamente com esse outro campo do empresariado, que foi decisivo no financiamento econômico da ditadura, sobretudo a partir do AI-5, que eram as empresas de exploração imobiliária, ou, como se diz hoje, as construtoras ou empreiteiras (Odebrecht, Camargo Correia, Lopes etc.).

Quem passa nas avenidas Marginal Pinheiros e Marginal Tietê e vê no alto dos prédios as luzes daqueles anúncios das imobiliárias, que acendem e apagam sem cessar, não pode avaliar o que isso significava para nós em 1970, 1971 e 1972; elas simbolizavam a presença de um olhar que via tudo e vigiava tudo. O nosso pavor era tão grande que achávamos que aquele apagar e acender de luzes era sinal de algum código de vigilância. Foram as construtoras que enriqueceram (construção de estradas, como a Transamazônica e ponte Rio-Niterói, de hidrelétricas, como Itaipu, de aeroportos, de avenidas como as que passaram a cortar São Paulo de ponta a ponta etc.) e sustentaram o aparato policial do Estado, da repressão. A figura que melhor simboliza esse poderio ilimitado sobre o espaço - a rua e os edifícios é, em São Paulo, a Avenida Paulista. Nesse período, uma cidade como São Paulo foi destroçada: com as 
demolições, perdeu não só os referenciais da memória urbana objetiva, como também mudou de sentido. Como diz Ismail Xavier, a cidade de São Paulo era uma cidade-sistema: tinha seus bairros claramente demarcados, a região fabril, a região comercial e financeira, a região habitacional com bairros de imigrantes e migrantes, os de classe média e os da burguesia (os famosos "jardins"); porém, sob a ação das empreiteiras e de Paulo Maluf, ela tornou-se uma cidade-arquipélago, desmembrada, com regiões auto-suficientes ou fechadas sobre si mesmas, sem centro, mas com grandes periferias; uma cidade feita para ser atravessada e não para se estar nela. A ideologia do "Brasil Grande" produziu a versão subdesenvolvida, caricatural, poluída, insuportável de Los Angeles.

\section{0 autoritarismo na América Latina}

O segundo tema que se discutia era a questão do autoritarismo na América Latina, ou seja, sobre as ditaduras instaladas no continente sob a direção do Departamento de Estado norte-americano (fundamentado na ideologia da Guerra Fria). Esse é um período (que dura pelo menos até o final dos anos 1980) em que a repressão praticada pelas ditaduras provoca um enorme entrelaçamento e intercâmbio das esquerdas, das universidades, dos intelectuais de um modo geral e dos movimentos sociais que surgem na América Latina. E cada um se exila no país do outro; há os que se exilam no Chile, depois os chilenos se exilam no Brasil, há os que se exilam na Argentina e depois os argentinos se exilam no Brasil; o mesmo acontecia com uruguaios e paraguaios, depois com peruanos e bolivianos, e assim por diante. Havia uma troca contínua dos exilados 
e isso produziu uma presença que tornou, pela primeira vez para nós, brasileiros, aquilo que era óbvio para todos os outros da região: a existência de algo chamado América Latina (nossas referências eram sempre a Europa e os Estados Unidos, ou, como os demais latino-americanos diziam, estávamos de costas para o nosso continente). Havia um debate que, de alguma maneira, estava polarizado entre duas interpretações a respeito desse autoritarismo: seria ele uma resposta a uma necessidade histórica (política) ou a uma necessidade econômica (o surgimento do capital multinacional)? Pela esquerda, vinha a explicação econômica, através de Enzo Faletto (Flacso contra Cepal) e Fernando Henrique Cardoso (Cebrap), isto é, a teoria da dependência. Pela direita, partindo do sociólogo espanhol radicado nos Estados Unidos e ligado ao Departamento de Estado norte-americano, Juan Linz, vinha a explicação política, isto é, a diferença entre autoritarismo e totalitarismo, posição que foi encampada por intelectuais brasileiros como Bolivar Lamounier, Celso Lafer e José Guilherme Merquior.

A teoria da dependência propunha-se a explicar a América Latina pelo tripé Estado nacional-capital nacional-capital internacional (como se observa, embora seja uma teoria de esquerda, curiosamente, nela está ausente a luta de classes, e o proletariado não entra como agente social e político). O autoritarismo aparecia como conseqüência da fraqueza do capital nacional, que precisava de um Estado ditatorial para estabelecer a relação com o capital internacional. Por seu turno, Juan Linz dava-se como tarefa a defesa do franquismo. E para isso propunha uma tipologia para diferenciar o autoritarismo do totalitarismo, 
afirmando que este último é a forma política do marxismo e se distingue do autoritarismo porque é imóvel, sem contradições, desprovido de história, fixado, de uma vez por todas, sob a forma da coação, da repressão, do supertrabalho e do domínio do Estado; sobretudo, é uma ideologia (entendendo por ideologia não o conceito marxista, e sim a concepção de muitos sociólogos norte-americanos, para os quais ideologia é um conjunto coerente de idéias que explicam a totalidade do mundo e são defendidas por um partido político). O autoritarismo, em contrapartida, não é uma ideologia; é temporário, limita algumas liberdades, mas não todas, opera politicamente sob uma Constituição e com o Poder Legislativo etc. Na América Latina, havia autoritarismo como defesa do continente contra a ameaça do totalitarismo, isto é, do comunismo.

\section{Democracia e socialismo}

O terceiro tema que nos ocupava era a questão da democracia e do socialismo. Como disse o Cicero, o grupo do Cedec considera-se socialista, mas a discussão "democracia e socialismo" não se confinava, evidentemente, às discussões feitas no Cedec.

O horizonte de referência que balizava a discussão sobre a relação entre democracia e socialismo era dado, de um lado, pela obra de Norberto Bobbio e, do outro lado, por Ernesto Laclau. Bobbio, a partir de uma análise da política italiana, trabalha com a separação entre democracia e socialismo. No caso do Laclau, essa distinção é posta, fundada, na distinção entre política e economia. Laclau afirma que o socialismo é uma concepção da economia, mas a democracia é uma concepção da política e ambos não possuem uma articulação interna ou intrínseca, 
tanto assim que há socialismo sem democracia (dá no que deu, mas tem socialismo) e democracia sem socialismo, como em todo o Ocidente. Em outras palavras, a separação entre ambos não é só de fato ou empírica, mas de direito.

Além da referência Bobbio-Laclau, havia também os trabalhos de um grupo marxista, que começa na Alemanha, produz uma revista naquele país e depois prossegue nos Estados Unidos, conhecido com o nome de Kapitalstaat, com nomes como Claus Offe, Elmar Altvater e Jürgen Habermas, que participou no início do grupo e depois se afastou. No caso de Kapitalstaat, em decorrência da política alemã, a relação entre democracia e socialismo era discutida a partir dos limites da social-democracia e de sua crítica. É desse grupo que provém, sobretudo com Offe e Altvater, a primeira análise do Estado do Bem-Estar Social como crise fiscal do Estado, numa perspectiva marxista oposta aos dos que, à direita, viriam a ser conhecidos como neoliberais (Hayek, Friedmann, Popper).

$\mathrm{Na}$ América Latina, além dessas referências, o quadro de discussão do tema estava também ligado, de um lado, ao que era denominado como "crise do marxismo-leninismo", isto é, à crítica do vanguardismo leninista (e às suas variantes guerrilheiras) como modelo do partido revolucionário e, de outro, a uma reflexão sobre o populismo e o caudilhismo, marcas profundas da AL, bem como sobre a natureza dos partidos políticos, o pluripartidarismo e os limites da democracia liberal.

\section{Análise e crítica da ideologia}

O quarto ponto que ocupava as discussões, os debates e os trabalhos, era a análise e a crítica da ideologia, no sentido marxista - expressão da luta das classes 
ou conjunto de idéias e valores da classe dominante, interiorizados por todas as classes sociais. Ou seja, a perspectiva oposta à da tradição sociológica de direita, isto é, de identificação entre ideologia e conjunto coerente de idéias defendidas por um partido político de esquerda. As discussões retomavam as análises de Gramsci sobre hegemonia e sobre a cultura. E começaram a ser feitas as primeiras análises sobre a ideologia da Segurança Nacional, espalhada por todo o continente latino-americano.

\section{A criação do Cedec}

É nesse contexto que é feita a proposta, em 1976, por parte de Francisco Weffort, da criação de um centro de estudos. Ele dava duas razões principais para a necessidade da criação desse Centro. A primeira, dizia, era porque "o Cebrap é economicista demais e passa ao largo das questões políticas, e nós precisamos de um centro que discuta as questões políticas"(Weffort era do Cebrap e o Cebrap era a nossa referência). Mas a segunda razão dada por Weffort, e isso foi mencionado pelo Cícero, era o fato de que começavam a se iniciar certos estudos na área das Ciências Sociais que não correspondiam - e eu vou explicar daqui a pouco por que não correspondiam - a uma certa tradição do trabalho acadêmico na área, não só em São Paulo, mas de, um modo geral, no Brasil.

Weffort reuniu um pequeno grupo. Das primeiras discussões que realizamos, participaram ele próprio, José Álvaro Moisés, José Augusto Guilhon Albuquerque, que vinha do Rio, mas tinha acabado de chegar da França, com uma formação junto aos althusserianos, e eu. Depois, juntou-se a nós Luiz Eduardo Wanderley, que seria depois o reitor da PUC e foi quem arranjou 
o espaço no qual o Cedec existiu inicialmente, uma casinha em frente à PUC, lá na rua Monte Alegre.

Fizemos muitas e muitas discussões e, finalmente, decidiu-se que era possível, interessante e necessário criar esse centro de estudos; mas, para que ele pudesse agregar o maior número de pessoas, era bom que introduzíssemos em seu nome a palavra "cultura", pois era preciso entender a cultura política, a cultura tal como vista pelos antropólogos, a questão da cultura popular, o problema da ideologia, a questão gramsciana da cultura e a luta pela hegemonia. Enfim, a palavra "cultura" tinha um alcance acadêmico, político e histórico suficientemente amplo para agregar muita gente - e é por isso que ele nasce com esse nome estapafúrdio, que é o Centro de Estudos de Cultura Contemporânea. Weffort era o presidente, eu a vice-presidente, Moisés era o secretário e Luiz Wanderley era o tesoureiro. E nós tínhamos lá aquela casinha, e as coisas aconteciam...

O Centro nasceu marcado pelo pluralismo. Participavam dos seminários, dos debates e das discussões todos aqueles que fossem contra a ditadura: a única condição para participar do Cedec era ser contra a ditadura. Na fase inicial, vocês vão ver nomes que hoje os fariam dizer: "Puxa, estavam no Cedec! Que coisa!”. O Cedec não incluía só a esquerda. Incluía, por exemplo, os liberais progressistas contra a ditadura, gente como Celso Lafer e Almino Affonso, por exemplo. Um dos seminários mais interessantes que nós tivemos logo no início, quando os exilados começaram a voltar, foi feito pelo Miguel Arraes. Incorporaram-se ao grupo Plínio de Arruda Sampaio, vindo da Democracia Cristã, o pessoal da $\mathrm{OAB}$, da $\mathrm{ABI}$, por intermédio de 
Perseu Abramo, o pessoal do Cebrap - uma parte do Cebrap passou a participar dos dois Centros -, o pessoal da Ciência Política da PUC, das Ciências Sociais da USP, os grupos ligados à Teologia da Libertação e a Paulo Freire.

Quero agora ler dois textos. O primeiro encontrase no primeiro número da revista do Cedec, de 1978, no qual a revista é apresentada e, nessa apresentação, o Cedec também é apresentado:

"No quadro atual da sociedade brasileira, torna-se cada vez mais importante estabelecer condições propícias ao estudo e ao debate das questões mais inquietantes que desafiam as sociedades latino-americanas. $\mathrm{O}$ nosso ambiente de criação da cultura esteve quase sempre ligado à expansão das funções estatais, contribuindo para favorecer um estilo de trabalho intelectual cujo protótipo em épocas mais recentes é o tecnocrata, reavivando as raízes autoritárias da tradição da cultura brasileira. Cumpre, nos dias que correm, criar condições para o desenvolvimento de visão crítica do passado e do presente, reafirmando suas ligações com a perspectiva de democratização econômica, social e política de nosso país. Trata-se de incentivar o debate através do qual se possa afirmar a riqueza da pluralidade e da diversidade do pensamento, fundamental para o desenvolvimento político e cultural nacional. Trata-se de recuperar traços do desenvolvimento histórico da sociedade que a ótica autoritária sempre ajudou a desarticular, mas cuja potencialidade inovadora e crítica o quadro cultural brasileiro já anuncia. É com esse espírito que é proposta a , cuja realização no tempo procurará responder a esses desafios. Para isso, convidamos todos aqueles identificados com esses objetivos amplos para nos ajudar cooperando e criticando". 
O segundo texto é do primeiro boletim no qual se expõem os primeiros esforços feitos pelo Cedec de criar um centro de documentação e de passar a informação sobre esse centro aos interessados. A apresentação dessa publicação e da existência do centro de documentação é feita da seguinte maneira:

"O Cedec é uma instituição civil, sem fins lucrativos, fundada em 1976, e cujo objetivo principal consiste na consolidação de um espaço para a realização de pesquisas e debates sobre aspectos sociais, políticos, econômicos e culturais da realidade brasileira, com ênfase especial na problemática das classes populares. É assim que o perfil do Cedec se define. Nesse sentido, dirige as suas atividades para as seguintes áreas: movimento operário e sindical, trabalhadores rurais, movimentos sociais urbanos, cultura popular, violência e marginalidade, igreja e suas relações com os movimentos populares e o Estado, ideologia e partidos políticos”.

Esse é o perfil do Cedec.

O setor de documentação do Cedec, criado em 1978, tem como objetivo a constituição de um acervo básico de informações para o estudo do processo de participação social, política e cultural das classes populares dos grandes centros urbanos do país - São Paulo, Rio de Janeiro, Porto Alegre, Recife e Belo Horizonte. Esse acervo vai basear-se em fontes primárias - documentos de associações populares e de sindicatos - e fontes secundárias - análise da grande imprensa. As dificuldades enfrentadas por pesquisadores nas áreas de movimentos sociais eram de aceitação no universo acadêmico universitário das Ciências Sociais, que era onde se faziam os estudos dos movimentos sociais, dos movimentos populares, e 
essas dificuldades são bastante conhecidas. Mas também havia dificuldades com relação aos documentos, uma vez que documentos e noticiários referentes às atividades culturais, sociais e políticas das classes populares são precariamente preservados. A publicação desse boletim, portanto, deriva do interesse do Cedec em divulgar a todos os interessados o conteúdo do seu acervo.

Considero que esse pequenino texto é a certidão de batismo e de crisma do Cedec. Vistos hoje, lidos hoje, e, sobretudo, por vocês jovens, esses textos não parecem ser nada de novo, nada de muito interessante, nada que já não se saiba a respeito da sociedade e da política brasileiras. Eu lhes garanto que, na época, isso foi uma revolução teórica e prática. Deixem-me dizer-lhes por quê.

Quando era menina e adolescente, aprendi História do Brasil, e depois, na universidade, tive, na disciplina de Sociologia, ministrada para o curso de Filosofia, uma pequena introdução à Economia e à Ciência Política. Vou contar, primeiro, qual foi minha experiência como aluna, como aprendi História na escola - não sei se vocês aprenderam assim, espero que não: Descobrimento, Capitanias Hereditárias, Governo Geral, Inconfidência Mineira, Família Real, Reino Unido de Brasil, Portugal e Algarve, Independência, Primeiro Reinado, Regência, Segundo Reinado, Abolição, Proclamação da República. Ou seja, o que aprendi na escola é a história do Estado brasileiro. Quais eram os textos? À direita, Capistrano de Abreu, Oliveira Lima, Alberto Torres, Oliveira Viana, Miguel Reale, Plínio Salgado e outros; à esquerda, Caio Prado, Celso Furtado, Richard Morse, Emília Viotti da Costa, Fernando Novaes, Wanderley Guilherme dos San- 
tos, Werneck Vianna. Surpreendentemente, dos dois lados, a História do Brasil é contada como a história do Estado Brasileiro.

Agora, conto o aprendizado na universidade. Novamente, a história econômica e a história social e política do Brasil são a história do Estado brasileiro. É assim que se passa nos textos do ISEB (Instituto Superior de Estudos Brasileiros) e nos cursos e nas teses das Ciências Sociais da USP.

O Iseb, que se articulou no Rio de Janeiro, ligado à presidência de Juscelino Kubitschek, para propor um programa de desenvolvimento para o Brasil, é criado por intelectuais comunistas, da esquerda não-comunista, liberais e progressistas. Os textos do Iseb trabalham com a ideologia desenvolvimentista e propõem o desenvolvimento do Brasil a partir do Estado. As Ciências Sociais da USP - Florestan Fernandes, Fernando Henrique Cardoso, Octavio Ianni - escrevem sobre o negro na sociedade de classes, mas o negro é apresentado por eles como um objeto passivo, que sofre a violência branca e nunca como um agente social ou político. Dessas Ciências Sociais, acrescidas da Economia, vem o Cebrap e, nele, a Teoria da Dependência, na qual os agentes históricos ou os sujeitos históricos são o capital nacional, o capital internacional e o Estado; não faz parte dessa teoria o proletariado, que sequer é mencionado. Numa palavra, a sociologia paulista produziu uma explicação sobre o Brasil e a AL na qual não entra a luta de classes. Não só isso. Como tudo é pensado a partir do Estado, aqueles que estavam "lá embaixo", que a Sociologia chama de "as classes subalternas" - acho uma beleza essa terminologia da Sociologia -, essas não entram nessa famosa teoria que guiou a esquerda da América Latina durante anos a fio. Não é casual, portanto, que os teóricos e pra- 
ticantes da guerrilha propusessem a revolução como a tomada do Palácio de Inverno - que foi o que os bolcheviques fizeram -, ou seja, a idéia de que a revolução é a tomada do aparelho do Estado.

É sob essa perspectiva que falo no Cedec como inovação conceitual, como uma verdadeira revolução no modo de pensar o Brasil.

Tenho aqui o primeiro livro que o Cedec publicou, e foi a primeira tentativa que fiz de estudar o Brasil. Vou pedir a vocês permissão para ler um trechinho, no qual tento compreender como a História e as Ciências Sociais eram feitas no Brasil. Peço desculpas de citar um texto meu, mas como ele é fruto do trabalho do Cedec, acho que pode ilustrar o que estou querendo dizer. O trecho é o seguinte:

"Mesmo não contando com a multiplicidade de interpretações, percebi que todas diferem, seja pela escolha das determinações que decidem o curso dos acontecimentos, seja pela maneira de combinar as determinações. Todavia, o arcabouço conceitual empregado é quase sempre o mesmo e possui os seguintes traços gerais [isso vale para os historiadores, para os sociólogos, para todo mundo]: 1) ausência de uma burguesia nacional plenamente constituída, tal que alguma fração da classe dominante possa oferecer-se como portadora de um projeto universalizante que legitime sua hegemonia sociopolítica. Não que tais frações de classe deixem de ter seus próprios interesses e de os reconhecer como seus através de práticas específicas, e sim que nenhuma delas tem condições para pôr-se como universal ou como classe dirigente; 2) ausência de uma classe operária madura, autônoma e organizada, preparada para propor e opor um projeto político que desbarate o das classes dominantes fragmentadas. Não que a classe 
operária esteja passiva, mas sim que suas formas de luta são inoperantes para pô-la explicitamente na cena política na qualidade de um ator principal;

3) presença de uma classe média urbana de difícil definição histórico-sociológica, mas caracterizada por uma ideologia e por uma prática heterônomas e ambíguas, oscilando tanto entre uma posição de classe atrelada às frações da classe dominante, quanto radicalizando-se à maneira pequeno-burguesa, atrelandose à classe operária para emperrá-la e frear sua prática revolucionária; 4) as duas primeiras ausências, no que tange às classes fundamentais, e o radicalismo inoperante, no que diz respeito à classe média urbana, engendram um vazio de poder que será preenchido pelo Estado com apoio de setores das Forças Armadas. O Estado surge, pois, como único sujeito político e como único agente histórico real, antecipando-se às classes sociais para constituí-las como classes do sistema capitalista. O Estado cumpre essa tarefa transformando as classes sociais regionalizadas em classes nacionais, exigindo que todas as questões econômicas, sociais e políticas sejam encaradas como questões da nação. Nascido do vazio político, pela ausência das classes fundamentais, o Estado é o sujeito histórico do Brasil; 5) no tocante à classe operária, mesmo quando admitida como ameaça à dominação burguesa, a ação da Terceira Internacional e do prestismo, de um lado [não é o que eu penso, os teóricos é que falam], a importação do anarquismo e do anarco-sindicalismo, de outro lado, conjugados com a origem imigrante e camponesa dos proletários [essa forma grosseira como coloco aqui aparece de modo sofisticado em vários cientistas sociais, mas ela também aparece dessa forma em muitos textos], desviam a classe da sua tarefa histórica e culminam com o populismo. Do lado de cima, há o vazio, e do lado de baixo, o desvio. 
Explicam-se os dois na medida em que o capitalismo no Brasil é atrasado, tardio ou desigual e combinado face ao capitalismo internacional, de sorte que a conseqüência não se faz esperar. O Estado é a fonte da modernização e é ele que terá que promover o desenvolvimento capitalista, que é a finalidade da história mundial; 6) no que concerne à formação das ideologias, o quadro anterior revela que nenhuma das classes pode produzir uma ideologia propriamente dita, isto é, um sistema de representações e de normas particular e dotado de aparente universalidade capaz de impô-lo à sociedade como um todo, de sorte que tanto o liberalismo, quanto o autoritarismo nacionalista, como os projetos revolucionários, são incapazes de exprimir, seja na forma do falso, seja na forma do verdadeiro, a realidade brasileira. Assim sendo, torna-se inevitável que o ideário liberal, o ideário autoritário e o ideário revolucionário sejam importados e adaptados às condições locais, resultando disso que, no Brasil, as idéias estão sempre fora do lugar."

O que preocupa nesse quadro é que, apesar da ênfase diferenciada que os intérpretes dão aos aspectos mencionados ou à questão da classe média, ou das oligarquias etc, em qualquer das interpretações há dois pontos problemáticos. O primeiro deles, em geral malgrado o próprio autor, é o pressuposto implícito: porque o capitalismo tem de se desenvolver, mas o faz com atraso e tardiamente, o Estado é obrigado a assumir a forma e os compromissos que assume. O segundo é o de que - isso também malgrado os próprios autores - o Estado assume o papel de sujeito histórico porque a luta de classes não chega a se exprimir de maneira suficientemente nítida no interior da sociedade civil. Em qualquer dos casos, porém, a conclusão é a mesma: o sujeito histórico é o Estado e não as classes sociais e a luta de classes. 
Esse quadro é preocupante porque deixa entrever que, guardadas todas as diferenças e matizes entre os autores, no plano descritivo e interpretativo a visão do Estado e da sociedade presentes à esquerda e à direita não são muito diferentes. A diferença se reduz ao seguinte: os intérpretes à esquerda dizem que, no Brasil, o autoritarismo teve que ser a solução para os problemas do país, enquanto à direita se diz que deve ser a solução. Afora essa pequena diferença entre o dever ser e o ter que ser, as análises à direita e à esquerda são quase idênticas. A impressão deixada pelo arcabouço conceitual empregado é a de que os intérpretes de esquerda não trabalham com a idéia de contradição, mas, como os de direita, com a de privação, de falta ou de ausência. De maneira que os períodos históricos e a sociedade brasileira são explicados por aquilo que lhes falta e não por aquilo que os engendra. O Brasil é explicado segundo lhe faltem isso e aquilo, ou seja, na cabeça dos autores está a sociedade capitalista européia como paradigma de uma realidade completa em comparação com a qual a brasileira é lacunar e incompleta e o Estado vem preencher a lacuna ou a privação.

Ora, o que o Cedec propõe, não só quando ele agrega todos os que são contra a ditadura, mas quando agrega várias tendências de esquerda e quando chama a si os estudos fragmentados que estão sendo feitos sobre os movimentos populares e os movimentos sociais, fazendo as publicações, as revistas, os livros? Propõe uma mudança de foco da análise sobre o Brasil. Ou seja, o social entra em cena novamente. Os estudos, os seminários, os debates, as publicações, as pesquisas do Cedec, ou de pessoas que fazem esse trabalho nas universidades, em outros centros, mas estão vinculadas ao Cedec, o que todos dizem é: a sociedade brasileira existe, as classes sociais existem e a luta de classes existe. Nascem os primeiros trabalhos 
sobre os movimentos sociais e os movimentos populares, temas até então inexistentes na História e nas Ciências Sociais brasileiras.

Ora, isso tem conseqüências políticas (e elas eram o que interessava ao Cedec, sobretudo ao Weffort): quando o Estado deixa de ser o sujeito histórico e quando a transformação histórica deixa de ser pensada como tomada pelo Estado, quando os movimentos sociais, os movimentos populares, os movimentos sindicais, a cultura popular, a questão dos partidos políticos, as formas sociais e políticas da organização surgem como os novos sujeitos históricos ou como um sujeito histórico coletivo, como disse Eder Sader, há uma redefinição da prática social transformadora. Aparece, tanto no plano do trabalho industrial como nas demais instituições sociais, o tema da autogestão em oposição ao tema sociológico da organização. E, no plano político, o tema da autonomia em oposição ao tema leninista da vanguarda. Com esses temas, entra em cena a discussão intensa sobre a noção de participação. Com a proposta da autogestão do lado do trabalho, da autonomia dos movimentos sociais e populares, do lado da sociedade, e da participação, do lado social e político, o Cedec encontrou os três elementos ou as três determinações que lhe permitiram fazer uma reflexão sobre a relação entre democracia e socialismo. Por isso mesmo, contrariamente a Bobbio e Laclau, nós, do Cedec, consideramos que democracia e socialismo são inseparáveis.

O passar do tempo fez seu trabalho. Hoje, o legado do pensamento inicial do Cedec está incorporado nas reflexões das Ciências Sociais e da Filosofia Política brasileiras e contribuiu para a defesa e concretização das práticas de participação política.

Obrigada. 
Cicero Araujo: Obrigado, Marilena. Passo agora a palavra ao professor Marco Aurélio Nogueira.

Marco Aurélio Nogueira: Peço licença para começar com uma observação de caráter pessoal. Faço parte de uma geração que cresceu tendo o Cedec como referência para o trabalho intelectual e para a interação política com a sociedade brasileira. Os trinta anos desta instituição coincidem com os trinta anos de vida da minha universidade, a Unesp, e com minha própria trajetória de professor universitário. Não se trata, portanto, somente de uma instituição relevante em si, mas de uma instituição relevante para mim. No entanto, ainda que me sentindo parte integrante do mesmo processo que objetivou o Cedec, na exposição que se segue, procurarei me colocar em uma posição "externa" a esse processo, buscando atuar como analista e não como "biógrafo" da instituição.

O presente texto não é sistemático nem muito menos conclusivo. Pretende privilegiar as relações entre o pensamento democrático de esquerda - aqui tomado como a família mais vigorosa do amplo universo da esquerda - e o processo que, ao longo de três ou quatro décadas (justamente as do nascimento e afirmação do Cedec), pavimentou o caminho brasileiro para a democracia política. Define-se como uma proposta preliminar de discussão. Sua inquietação é tentar compreender o que ocorreu nesse arco de tempo, de onde partiu e aonde chegou a esquerda que participou com voz ativa da luta democrática, impulsionou-a e, mais tarde, agiu para modelá-la e governá-la.

O que pensava a esquerda na virada dos anos 1970 para os anos 1980 no Brasil? Quais os eixos e focos de seu posicionamento teórico-político, quais suas influências e suas proposições? 
Uma primeira aproximação a esse problema pode ser feita com a afirmação de que, no Brasil daqueles anos, constituía-se um pensamento que não se propunha apenas a derrotar a ditadura militar na qual se vivia, o poder do Estado capitalista então estabelecido. Seu desafio era também o de pensar a democratização, entendida como um processo de recomposição e alargamento do sistema político, de incorporação e integração social, de expansão e consolidação da democracia em sentido amplo. Poder-se-ia também dizer que se estava repondo em novas bases o tema da emancipação, ainda que isso não se explicitasse plenamente. Era essa a marca de identidade do pensamento teórico de esquerda que se mostrava mais criativo e profícuo naquele período.

Sua agenda incluía tanto uma reflexão sobre a sociedade na qual se vivia e sobre os sujeitos que nela atuavam e nela buscavam lugar, quanto uma reflexão sobre o sistema de regras que deveriam ser adotadas para que se pudesse disputar democraticamente o poder e, em termos táticos mais diretos, encurralar e superar a ditadura. Enfatizo, aqui, a idéia de superação. Tratava-se seguramente de derrotar a ditadura, mas também de armar o passo seguinte e preparar desde logo o caminho para a reconstrução democrática e a reorganização da sociedade que sairia da ditadura. Sabia-se - ou ao menos se intuía - que este não seria um movimento simples ou fácil. Afinal, seria necessário promover o encontro da sociedade com os novos ventos que começavam a soprar no mundo (globalização, alterações no padrão da vida moderna, desagregação do bloco soviético e do marxismo a ele associado), ao mesmo tempo que equacionar seus próprios dilemas históricos e acelerar o esta- 
belecimento de melhores patamares de desenvolvimento, justiça e igualdade. Parafraseando o texto famoso de Joaquim Nabuco ( $O$ abolicionismo), partia-se do suposto que era preciso certamente acabar com a ditadura, mas também destruir o que sua obra tinha de horror, de atrofia e distorção do país, de rebaixamento político da sociedade.

Em segundo lugar, aquele pensamento voltava-se para o tema da representação política, procurando consolidar uma reflexão que fosse crítica da idéia liberal de representação mas que também se mostrasse capaz de negar e ultrapassar a idéia imperativa ou vinculada de representação, mais típica de certas variantes da esquerda. Buscava-se estabelecer uma idéia de representação entendida não de maneira corporativa e, portanto, não segundo o princípio que advoga que o representante deve se comportar e agir de acordo com instruções recebidas de quem o elegeu, mas de acordo com uma idéia política de mandato. Buscava-se pensar a representação, mediante a fórmula italiana da "democracia de massas", na qual a participação era concebida como ocupando um papel central na formatação de um novo sistema representativo que, por ela, seria "alargado" e revigorado.

\section{Democracia progressiva e protagonismo social}

Em seu conjunto, isso implicava incorporar o tema da democracia progressiva, conforme o registro do marxismo italiano, que se generalizava como a mais importante influência teórica sobre a esquerda do período. O Partido Comunista Italiano havia consagrado essa expressão, desde os anos que se seguiram ao final da II Guerra, para qualificar um processo e uma cultura que se abrissem permanen- 
temente para a reforma e procurassem projetar sua dinâmica em direção ao que se imaginava ser o socialismo. Do ponto de vista teórico, tal proposição implicava pôr em xeque algumas coisas muito cristalizadas e complexas, a começar do parâmetro ideológico, teórico e cultural da própria esquerda, que era o marxismo dogmático, o marxismo duro, a religião marxista, o marxismo-leninismo e toda uma série de versões desse universo. Significava pôr em xeque, também, a social-democracia tradicional, que já havia travado seu embate com esse marxismo mais dogmático e mais duro sem conseguir configurar nenhuma alternativa efetiva a ele. E significava, enfim, entrar em choque e superar o liberalismo em todas as suas derivações.

A idéia de "progressiva", naquele registro, aceitava a perspectiva de avanço processual mediante acúmulos, sedimentações e consolidações. Seguia a ênfase gramsciana que Palmiro Togliatti dera à defesa de uma democracia "que reconhece e afirma a tendência a uma profunda renovação social realizada na legalidade"1. Propunha-se antes de tudo, como ação positiva de transformação social, sinônimo de "um regime que, para salvar os direitos populares, o bem-estar e a paz, não fica parado, mas se move, avança, resolve a velha questão da terra, enfrenta a prepotência do capital e dos monopólios, atribui ao Parlamento e ao Estado tarefas distintas das do passado" 2 .

E foi assim que o tema entrou nos ambientes da esquerda que lutava pela democracia e contra a ditadura no Brasil daquele período.

${ }^{2}$ Togliatti, (1958)1966: 116. 
Não se tratava de uma idéia que excluísse o momento do antagonismo e da luta. Defenderse-iam o diálogo e a legalidade, mas nem por isso deixar-se-ia de atacar o adversário ou de buscar derrotá-lo nos âmbitos em que alicerçava sua dominação. Supunha-se, aliás, que o processo político era amplo, tenso e complexo. Os planos e níveis a serem transformados estariam de tal modo superpostos e entrelaçados que apenas o ataque simultâneo a todos eles - mediante uma sucessão de reformas concatenadas, distribuídas em um tempo que não se podia determinar de antemão - garantiria avanços substantivos. Mais que conquista do poder, privilegiava-se a luta pela hegemonia, a construção de capacidades intelectuais e morais para dirigir a sociedade, como diria Gramsci, autor que adquire grande destaque no Brasil do período.

A versão brasileira da democracia progressiva, portanto, não se voltava somente para o bom funcionamento do sistema político ou para a colocação em prática de operações que promovessem maior sintonia entre governantes e governados. Seu sentido principal estava dado pela busca da reforma social na legalidade democrática, pela ativação de uma dialética Estado/sociedade que fizesse de cada conquista a base e o impulso para novas e mais importantes conquistas sucessivas, à imagem e semelhança de um processo reformador radicalizado e permanente. Precisamente por isso, política e cultura estavam destinadas a caminhar juntas, uma alimentando a outra.

Tal empreendimento cultural, político, ideológico, está nas origens tanto do Cedec quanto da luta pela redemocratização no Brasil. Pela esquerda, era esse o passo que se pretendia dar. Sua principal tra- 
dução prática foi a política de frente democrática que, posta como questão estratégica pelos comunistas no final dos anos 1950 e impulsionada pelos embates contra a esquerda armada nos anos 1960, ganhou corpo e se afirmou pouco a pouco a partir de meados dos anos 1970.

Além dessa agenda de natureza geral (a renovação do pensamento de esquerda e do marxismo, o encontro de novas formas de lutar contra o capitalismo que já dava mostras de se reforçar, a incorporação ativa da democracia à perspectiva da emancipação e do socialismo), havia também uma agenda mais particular. Estávamos obrigados a entender a particularidade brasileira e precisávamos traduzir o esforço de inovação teórica em termos nacionais, de modo que se alcançassem os adversários teóricos, políticos e ideológicos enraizados no Brasil.

Tal fato projetava o pensamento de esquerda para uma posição contrária, antes de tudo, ao liberalismo conservador brasileiro, que havia, ao longo da história, conseguido sufocar as vertentes liberais mais democráticas, colocá-las à margem e submetêlas. Em decorrência, tratava-se de um pensamento que se punha como aliado estratégico do liberalismo democrático. Entrava-se também em atrito com o populismo que, a partir dos anos 1930, se incorporara à trajetória do Estado brasileiro, cumprindo importantes funções dedicadas à organização da classe operária, mas bloqueando seu pleno amadurecimento político. Por extensão, estabelecia-se um diálogo crítico com o sindicalismo que tivera no Brasil uma trajetória extremamente acidentada, com fortes entonações corporativistas. E armava-se uma tensão com o nacional-desenvolvimentismo, que, vindo dos anos 1950, ainda se mostrava forte 
no início da redemocratização, com seu "estatismo" meio unilateral que pouco espaço concedia aos atores sociais, ou que somente os concebia como seres subalternos ao Estado. Já discutimos muito o nacional-desenvolvimentismo e, certamente, continuaremos a fazê-lo, dada sua relevância para a construção do Estado entre nós. Nos anos a que estamos nos referindo, a melhor crítica o abordava como uma posição que atribuía grande força à dimensão estatal num momento em que já se começava a ter uma sociedade civil mais complexa e mais bem constituída como âmbito de ação política.

O grande objetivo a que se propôs o pensamento democrático de esquerda entre os anos 1970 e 1980, e depois, foi o de valorizar e qualificar no plano teórico aquilo que no plano da sociedade já se anunciava como novidade, qual seja, o crescente protagonismo social, fazendo isso sem perder de vista que o eixo da democratização seria determinado pelo político. Em decorrência, aquele pensamento irá contrapor-se, em nome da democracia como valor universal, tanto ao tecnicismo institucional quanto ao voluntarismo e ao dogmatismo, que recusavam, cada um a seu modo, as razões da política e as difíceis opções impostas por elas. O tecnicismo vinha com as marcas da ditadura e de seu projeto de abertura controlada, e era por isso mais fácil de ser isolado. $\mathrm{O}$ dogmatismo, quase sempre de inspiração stalinista e afinado com um marxismo escolástico, enrijecido, pouco dialético, implicava a vedação da realidade e tendia para um problemático autoritarismo, acabando por se isolar a si mesmo. O espontaneísmo voluntarista, porém, trazia muitos complicadores, seja porque integrava a cultura de esquerda, seja porque encontrava respaldo nas transfigurações sociais que então ocorriam. A 
tudo isso o pensamento democrático de esquerda se contrapunha em nome da democracia progressiva ${ }^{3}$.

Aquele pensamento, assim, será em alguma medida o herdeiro e o tradutor daquilo que Gildo Marçal Brandão chamou de "esquerda positiva"

O novo quadro incentivaria a busca de novos caminhos. A luta contra a ditadura e a própria redemocratização também foram feitas em ritmo de reorganização partidária, para o que contribuiu bastante, por vias enviesadas, a repressão ditatorial que se abatera sobre as organizações de esquerda, dissolvera as agremiações partidárias tradicionais e reformulara o sistema de partidos. Especialmente no universo das esquerdas, assistiu-se a um dedicado esforço de inovação, em boa parte ancorado em idéias associadas ao marxismo italiano, mas também ao eurocomunismo (PCI, PCF, PCE), à socialdemocracia alemã e ao liberal-socialismo de Norberto Bobbio. Buscou-se ali projetar uma idéia diferente de regime democrático e de partido político, pensar com maior vigor a cidadania e fundamentar, portanto, uma idéia de democracia que fosse ampla e forte o suficiente para promover sucessivas reformas sociais.

Tal esforço manifestou-se nas tentativas de renovar e oxigenar o Partido Comunista Brasileiro, tanto

\footnotetext{
${ }^{3}$ A relevância que a questão da democracia teve na movimentação e nas reflexões que se faziam nos ambientes de esquerda no período pode ser verificada em Marco Aurélio Garcia (1986), que retém a parte mais substantiva de um seminário realizado no Cedec naquele mesmo ano. Conforme esclarece o organizador, o seminário foi balizado pela repercussão obtida, nos anos imediatamente anteriores, por três importantes textos: "A democracia como valor universal", de Carlos Nelson Coutinho (1979) também publicado em Francisco Weffort (1984) e em Daniel Aarão Reis Filho (1985). Além desses autores, participaram do livro Maria Victória Benevides, Régis de Castro Andrade e José Álvaro Moisés. Para uma avaliação das promessas e dificuldades do pensamento democrático no âmbito específico do Partido Comunista Brasileiro daquele período, ver: Konder (1980) e PCB (1982).

${ }^{4}$ Brandão (1997).
} 
quanto nas mudanças que se operaram no interior do Partido Comunista do Brasil, para falar de duas forças com peso específico relevante. Fez-se presente no movimento que levaria, no início dos anos 1980, à fundação do Partido dos Trabalhadores (PT). Pulsou no coração mesmo da política de frente democrática que aos poucos se firmou no país. Manifestou-se na Assembléia Constituinte de 1988, bem como no delineamento das primeiras medidas do governo Sarney, como o Plano Cruzado. Em todas essas manifestações, o eixo de esquerda pendia para uma específica forma de conceber o socialismo: ele somente poderia ser cogitado, como projeto e como empreendimento prático, se estivesse associado a uma revolução democrática que trouxesse consigo novas instituições representativas, novas formas de pensamento e cultura, maiores espaços de participação e modalidades mais adequadas de gestão e governo da sociedade.

\section{Redemocratização e capitalismo globalizado}

Mas o que aconteceu com aquele pensamento no correr da redemocratização e, sobretudo, depois que ela se completou? Suas promessas foram cumpridas? Se sim, quais foram cumpridas? Se não, por que não? Que transfigurações aquele pensamento e os partidos e movimentos que, com ele, se identificaram sofreram quando a luta deixou de ser "contra a ditadura" e passou a ser "por um governo reformador"? Ou seja, quando se passou da oposição ao regime para a gestão de um regime?

Não há nada simples aqui. A começar da própria redemocratização. Do que estamos falando efetivamente? Qual a sua duração, quando começa e quando termina? Se formos estabelecer isso a partir de algumas datas exatas, corremos o risco de ficar giran- 
do em falso. Para o que pretendo aqui, pode-se fixar a redemocratização como um processo que, embora tenha começado logo nos meses que se seguiram ao golpe militar de 1964, conheceu um ponto de inflexão específico, a partir do qual encorpou e começou a se espraiar, comendo progressivamente o campo do adversário. Vamos circunscrevê-lo ao período que vai de 1975 - ano dramatizado pela morte de Vladimir Herzog - a 1988, quando se tem a nova Constituição. Mas não haveria erro nenhum se se alterassem essas extremidades, de modo, por exemplo, que se fixassem o "início" da redemocratização em 1973, quando Ulysses Guimarães e Barbosa Lima Sobrinho participam como "anticandidatos" das eleições presidenciais indiretas de 1974, e o "fim" do processo em 1989, quando se tem a primeira eleição direta para Presidente, ou em 1994, quando Fernando Henrique Cardoso consegue levar a efeito uma experiência concreta de estabilização econômica, ou mesmo em 2002, quando Lula, um operário, chega ao poder.

Periodizações desse tipo servem-nos apenas como recurso analítico. Processos de redemocratização a rigor não têm data para começar e terminar, como sabemos. Fazem-se sem separações rígidas entre um "antes" e um "depois”, e são seguramente particularizados pelas condições concretas em que transcorrem. Justamente por isso, creio ser válido, e mesmo útil, aceitar uma distinção conceitual entre redemocratização e democratização, ou seja, admitir que a recuperação de um status anterior de vida democrática somente se efetiva quando se casa com a abertura de um ciclo superior de construção democrática. A destruição de uma ditadura, a rigor, só se completa quando se consegue dar início à edificação de um regime fir- 
memente comprometido com a democracia, legitimado socialmente e sustentado por uma cultura pública revigorada.

Nosso paulatino distanciamento em relação ao regime ditatorial de 1964 não conteve somente redemocratização em sentido estrito. Ocorreram muitos outros processos e transformações ao longo desse período, e tais fatos, por sua vez, condicionaram a redemocratização, dialogaram com ela, de certo modo, determinaram-na e formataram-na. A compreensão desses "outros" processos ajuda-nos decisivamente a entender tanto o ritmo da redemocratização quanto seus desdobramentos efetivos e seu legado para a democratização.

Seria possível falar da seguinte maneira: o processo político teve uma expressiva potência de destruição da ditadura, mas não teve igual potência para democratizar o país. Houve seguramente avanços em termos democráticos. O país tornou-se uma democracia, "revolucionou-se" em termos políticos, mas permaneceu distante da vida democrática plena. Os processos e transformações sociais que estiveram na base da luta contra a ditadura complicaram a passagem da redemocratização para a democratização e de certa maneira atropelaram o pensamento de esquerda e o esforço de inovação que estavam sendo gerados nas décadas de 1970 e 1980. A "transição pactada" ou pactuada foi mais uma imposição da realidade que uma escolha deliberada dos atores políticos.

A estrutura social brasileira modificou-se expressivamente no correr dos quarenta e poucos anos em que se foi afastando do golpe de 1964. Houve uma transfiguração socioeconômica fortíssima, ainda que a sociedade não tenha deixado de ser desigual, repleta de carências e contrastes extremos, com elites 
precárias e donos do poder quase primitivos em seu descaso pelo povo e pela democracia.

Antes de tudo, o Brasil capitalizou-se de modo insofismável, mesmo que caminhando a taxas reduzidas de crescimento econômico. Capitalizou-se no sentido de que se tornou inteiramente capitalista, seja em termos estruturais, seja em termos superestruturais, quer dizer, como modo de produção e como hegemonia, como economia e como cultura. Para empregar uma imagem cara a Negri e a Foucault, podemos dizer que também no Brasil o poder capitalista foi muito além da modelagem de uma estrutura produtiva e de uma organização do trabalho e ganhou dimensão "biopolítica": ocupou o conjunto das relações sociais, agitando-o e forçando-o a seguidas reconfigurações - invadiu "as condições

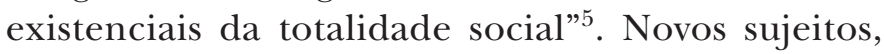
novos antagonismos e novas dinâmicas societais tornaram-se, assim, inevitáveis.

A sociedade "tradicional" continuou evidentemente a existir, mas foi como se, ao longo daquela transfiguração, tivéssemos assistido à constituição de uma espécie de "segunda sociedade", de opulência seletiva, de inovação tecnológica, de redes e comunicação intensiva, de sistemas midiáticos sofisticados e que, aos poucos, se justapôs ao Brasil tradicional, submeteu-o funcional e ideologicamente e passou a modelá-lo. Esta "segunda sociedade", de modernidade radicalizada, acabou por produzir dinâmica suficientemente forte para ir desorganizando (sem dissolvê-los por completo) os equilíbrios tradicionais.

Dizer, portanto, que o Brasil é um país capitalista não significa dizer que a vida "tradicional" desapare-

${ }^{5}$ Negri (2006: 206). 
ceu, mas sim que ela se subordinou a um capitalismo que prevalece por toda parte, que não apenas penetrou a estrutura econômica, como também se infiltrou na cultura do país e impregnou a alma da sociedade. Todos os cidadãos estão hoje "capitalizados", mesmo que nada ganhem com o capitalismo, mesmo que somente se relacionem com ele na condição de explorados. Praticamente desapareceram os espaços em que se podia praticar alguma experiência não-capitalista. Os próprios discursos anticapitalistas perderam força e foram obrigados a reciclar-se, a mudar a agenda, a incorporar novos temas e problemas. Tornaramse mais diversificados, menos "materialistas" e seguramente menos "nacionalistas", até mesmo porque a própria sociedade brasileira foi, progressivamente, se tornando mais globalizada e cosmopolita.

Ao longo dos quarenta e poucos anos que o foram afastando do golpe de 1964, o Brasil globalizou-se. Não somente aprofundou sua inserção subordinada no mercado mundial, como também se conectou ao mundo e se tornou mais condicionado pelo que acontece no mundo. Passou a compartilhar os principais traços da época: a mundialização das relações sociais, econômicas e políticas, a interconexão global, a frenética mobilidade dos capitais, a financeirização e a transnacionalização das economias, a segmentação e a expansão da oferta de produtos, a perda de soberania por parte dos Estados, a irresponsabilidade dos mercados, a crise da regulação e dos mecanismos de financiamento do setor público, e assim por diante. Todos esses fatores podem ser, sem dificuldade, associados a um quadro geral (nacional e internacional) de turbulência, imprevisibilidade e "descontrole", que teve extraordinário impacto sobre o político e a política, atropelando governos, sistemas e partidos. 
Quanto mais chegamos aos nossos dias, mais esse processo se aguçou, arrastando consigo os múltiplos arranjos sociais. As novidades na estrutura social e no modo de ser do capitalismo, ao lado de dificuldades crescentes em termos de governabilidade, de representação, de gestão econômica e de controle do território, passaram a desafiar o pensamento político de esquerda. O mundo ficou meio à deriva, refém de mercados irresponsáveis e submetido a políticas de potência unilaterais, invariavelmente influenciadas pelos Estados Unidos. Espaços sociais e territórios não puderam mais ser administrados como antes, a idéia de soberania mudou, os Estados nacionais perderam autonomia, seus sistemas se desestruturaram. O capitalismo turbinado, a modernidade, radicalizada em escala global, tornou-se um contexto de caos sistêmico, que não se limita a ser um cenário externo à sociedade, mas a invade toda, condicionando-a e modificando-a de maneira significativa.

Essa articulação de capitalização e globalização foi patrocinando o surgimento de uma nova realidade no mundo e, portanto, também no interior de cada sociedade particular. Sob o estímulo desse patrocínio, fomos passando a viver em uma "sociedade do risco" ${ }^{6}$, que problematiza padrões e certezas e revira as bases da vida em escala global e dentro de cada espaço social. Uma inédita intensificação da reflexividade faz com que tudo tenda a repercutir em tudo o tempo todo, seja no plano das idéias e informações, seja no plano das estruturas. Há uma "modernização da modernização", como diz Beck, e isso faz com que a dinâmica social fique "fora de controle". Não ingressamos, portanto, em uma simples fase de

\footnotetext{
${ }^{6}$ Beck (2001).
} 
mundialização do capital, mas em uma etapa delineada por "um fenômeno bem mais profundo e total, capaz de convulsionar e modificar as coordenadas essenciais da mentalidade coletiva e do ser social". A globalização é, na verdade, uma "revolução espacial", "uma transformação qualitativa e substancial da percepção social do espaço, ou se se preferir, da percepção do espaço social, ou seja, daquele âmbito em que se colocam os eventos considerados suscetíveis de influenciar diretamente e em tempo real a própria vida cotidiana”. ${ }^{7}$

Caminhando na esteira desse processo, o Brasil fragmentou-se muito e assistiu a uma inédita dispersão de seus centros de coordenação. Como a sociedade, ao mesmo tempo, também se individualizou, o processo, em seu conjunto, acarretou rarefação e perda de relevância das instituições, que foram se tornando menos eficazes e menos respeitadas, sempre prontas a ser "reformadas", ainda que quase nunca a ser efetivamente .

Capitalismo turbinado, modernidade radicalizada e globalização produzem inexoravelmente quebras institucionais e desorganização dos territórios sociais, quer dizer, daqueles espaços que alicerçam e dão identidade a indivíduos e grupos sociais. A reestruturação produtiva e as opções políticas feitas a partir dela (o "neoliberalismo) fazem com que o trabalho mude dramaticamente de configuração, alterando conseqüentemente o padrão da sociabilidade. Numa economia e num modo de vida incessantemente revolucionados pela tecnologia e que se automatizam com rapidez, a recomposição institucional é inevitável, e seus efeitos atingem, antes de tudo, as empre-

\footnotetext{
${ }^{7}$ Revelli (2003: 83).
} 
sas, as relações trabalhistas e os empregos. As possibilidades tecnológicas assim generalizadas, observa Sennett, "significam que a integração das massas - o elemento social do capitalismo - pode desaparecer. Precisamente, os membros mais vulneráveis da sociedade, aqueles que querem trabalhar, mas não dispõem de qualificação especializada, correm o risco de ser deixados de fora"8. A própria automação restringe o âmbito de aplicação de certas capacidades humanas. O desemprego estrutural dissemina-se sem freios, gerando mais tensão e desagregação social. Tudo isso, de forma combinada, desestrutura as classes sociais e os personagens do mundo político que as representam, vale dizer, os partidos políticos. $\mathrm{Na}$ verdade, a desorganização das instituições - o "sofrimento organizacional" ${ }^{9}$ - abala praticamente tudo: a família, a escola, o Estado, os sindicatos, as regras da competição, o mercado, o sistema político.

Com a objetivação impetuosa desse processo, as sociedades passaram a carecer de mecanismos eficientes de coordenação e articulação social. Suas partes e seus sujeitos afastaram-se uns dos outros e tenderam a seguir lógicas próprias - ainda que, paradoxalmente, tudo ficasse mais conectado. As sociedades civis, por sua vez, conheceram forte ativação, mas não se constituíram politicamente como teatro de efetivas disputas de hegemonia. Cresceram, amadureceram e diversificaram-se por efeito da maior explicitação dos interesses, mais como decorrência da competição que da busca de entendimentos e unificações, mais por pressão do mercado que por posicionamento diante do Estado. Com o passar do

${ }^{9}$ Nogueira (2005). 
tempo, tornaram-se paradoxalmente mais dinâmicas e mais desorganizadas.

Outros sujeitos passaram, assim, a povoar a cena social e a impulsionar a dialética das contradições, embora sem conseguir entrar de fato no jogo político e redirecioná-lo. A fragmentação corporativista da representação política aumentou, com efeitos perversos sobre o processo político: partidos e governos tornaram-se mais "dependentes" dos vínculos com os interesses particulares que estão em sua base; com isso, recuaram como representantes do "todo" e perderam agilidade no processo de tomada de decisões.

Como disse Vicente Palermo a respeito da situação argentina, "parte da crise de representação que nos afeta consiste em que as autoridades eleitas são, ou se sentem, tão débeis que por temor acabam sendo". Em decorrência, ficam sem "coragem suficiente" para caminhar contra os interesses "indignados" mesmo quando esses se mostram inteiramente descabidos ou contrários ao "interesse coletivo" ${ }^{10}$. Não seria difícil encontrar exemplos semelhantes no Brasil, algumas vezes até mesmo de forma reversa: são conhecidas as dificuldades que os governos têm para "convencer" seus partidários da validade de suas políticas, especialmente quando elas colidem com o que se imagina ser o "interesse coletivo".

\section{Modernidade periférica}

A radicalização do moderno ganhou componentes ainda mais perversos e turbulentos ao instalar-se na periferia. O Brasil modernizou-se, mas não deixou de

\footnotetext{
${ }^{10}$ Palermo (2006).
} 
permanecer estacionado em uma zona de subordinação econômica, retardo tecnológico (relativo) e desigualdade social profunda, com um padrão incompleto de cidadania.

A modernidade periférica é filha do colonialismo, da subalternidade e da dependência. É imperfeita e nãofuncional. Na periferia, as características emancipadoras do moderno perdem potência e evoluem de modo represado. Não se explicitam como passos efetivos de inclusão e de dignidade social revestidos de caráter universalizante. Mantêm-se enrodilhadas em formas naturalizadas de desigualdade, sendo, em boa medida, reconfiguradas por elas.

As sociedades periféricas experimentam hoje, no início do século XXI, todos os efeitos da modernidade radicalizada, mas não conseguem deixar de ser "pré-modernas". Assistem desprotegidas e confusas à subversão das formas tradicionais de vida, à fragmentação da sociabilidade, à irrupção frenética e errática de novos atores sociais, de novas formas de associativismo e de novas postulações de identidade e reconhecimento. Para usar uma imagem empregada por Ulrich Beck em outro contexto, os povos periféricos pensam como categorias de ordem da Primeira Modernidade, mas agem na "zona cinzenta e nas turbulências da Segunda"11. Miséria, exclusão social e desemprego estrutural misturam-se loucamente com restos de latifúndios improdutivos e de formas primitivas de exploração da mão-de-obra, bem como com as dinâmicas "deslocalizadas" do mundo digital e transnacional. Na periferia, a reflexividade moderna torna-se experiência cotidiana sem que se eliminem a exclusão, a marginalidade, as formas existenciais

\footnotetext{
${ }^{11}$ Beck (2003: 28).
} 
provincianas e presas ao passado. A violência urbana - não a do crime organizado, mas a que deriva das tensões existenciais das cidades - é somente um aspecto dessa situação.

Os próprios processos de democratização política ficam limitados e condicionados por este quadro geral. No caso brasileiro, a democracia conquistada pelas lutas contra a ditadura não chegou a institucionalizar-se plenamente nem a converter-se em cultura, e isso, tanto porque se expandiu em termos prevalentemente eleitorais sem um correspondente adensamento ético-político, quanto porque cresceu por fora do Estado, sem envolvê-lo e "responsabilizá-lo". Abriuse um fosso entre a movimentação social e a movimentação institucional, como se a segunda estivesse parada no ar, incapaz de reagir e de dialogar com a primeira, que progrediu derrubando todas as portas, roubando sentido e legitimidade das instituições, infernizando a vida organizada, desconstruindo e tornando improdutivos os governos, os partidos e os sindicatos. As pessoas votam, mas não se sentem representadas; participam, mas não se vêem como partícipes dos processos decisórios; lutam por direitos, mas não conseguem reconhecer-se como sujeitos de obrigações e deveres; há muitos direitos políticos e poucos direitos civis para a maior parte da população pobre, que também não dispõe de um patamar consistente de direitos sociais efetivamente praticados e usufruídos ${ }^{12}$.

O cenário que se abre a partir daí não é necessariamente apocalíptico. Ele desorganiza os parâmetros com que se pensava o mundo e com que se agia sobre o mundo, e porisso atemoriza, causa desconforto e sugere saídas aferradas a um passado que se valoriza 
intuitivamente. Não há como voltar para trás e recuperar a integridade dos fenômenos que compuseram a base da primeira modernidade. Classes sociais, nações, partidos e instituições políticas não voltarão a ser o que já foram, e pouca serventia tem o clamor nostálgico, até mesmo porque jamais houve nenhuma garantia de que a política feita com base naqueles parâmetros seria de melhor qualidade e nos levaria a uma sociedade mais justa. Além do mais, ao se alterarem as estruturas objetivas da vida social, deve-se mudar o modo de pensar e de agir sobre esta vida.

Estamos forçados a ser mais materialistas do que nunca: a estrutura da sociedade moderna - em sentido amplo: econômico, político e sociocultural - está mudando rapidamente e produzindo, no curso dessa mudança, alterações no plano dos projetos, das idéias e instituições. O nosso não é um mundo plasmado pelo neoliberalismo ou pelo consenso de Washington, por mais fortes que eles sejam. Ao contrário, é o projeto neoliberal que hoje se apresenta como produto de um novo mundo que surge e que tenta controlar, disputando com outros projetos o monitoramento de um processo objetivo que avança de modo inexorável.

Para o que interessa aqui, o fato é que esse processo de radicalização periférica do moderno reverberou como um terremoto sobre as forças democráticas que fizeram a transição e que com ela ganharam impulso. Despojou-as de sujeitos sociais de referência e animação, que se estilhaçaram, se diluíram e se recompuseram mediante lógicas complicadas. Impossibilitou-as de crescer de forma orgânica e em termos politicamente consistentes. E, acima de tudo, fez com que ficassem sem um pensamento articulado, tanto porque elas próprias deixaram de funcionar como usinas 
de idéias, quanto porque se aprofundou o hiato entre intelectualidade e vida política. O impacto desse terremoto foi desigual: atingiu com maior gravidade os pontos que estão mais à esquerda do leque.

\section{Despolitização e novas politizações}

Quanto mais caminhamos para o século XXI, mais a sociedade despolitizou:-se, entregou-se ao econômico, buscou refúgio no mercado e virou as costas para o Estado. Por essa via, os cidadãos passaram a desconfiar de seus políticos e de suas instituições, afastaram-se da política e viram a política ser reduzida a um amontoado de formas pragmáticas e incolores de gestão sistêmica. Permaneceu ativa, porém, uma expectativa social de "proteção" e cobertura estatal, sobretudo por parte dos setores mais marginalizados e de uma classe média que, desvalorizada e confundida, proclama seus direitos perante o Estado. Aumentou também a disposição societal de criar uma "zona de ação política" menos institucionalizada e mais subjetiva (individualista), de ação e movimentação contínua, de pressões difusas, erráticas, viabilizadas pelas maiores facilidades de comunicação e contato. Constituiu-se, assim, um impulso favorável a formas alternativas de politização, cujo teor ainda está por se explicitar.

Ao longo dos anos, os governos foram se dando conta de que não poderiam mais agir de modo unilateral e decisionista. De que teriam de "ouvir mais", negociar e assimilar a disposição societal que se anunciava, algumas vezes, pondo-se a serviço dela e, outras vezes, dialogando com ela e incorporando-a a suas políticas. Foi o que aconteceu, por exemplo, com a inclusão da participação no plano da gestão de políticas sociais, que repercute a aspiração por "democra- 
cia participativa" entranhada em muitos setores da sociedade civil e na própria cultura da época.

Mas a ação societal seguiu a mesma tendência do processo de revigoramento da sociedade civil: cresceu e avolumou-se, tendo como motor a afirmação dos interesses particulares, não a construção de consensos, projetos coletivos ou novas correlações de forças. Serviu como plataforma de lançamento de novas modalidades de politização, mas não as instituiu plenamente.

Por outro lado, a ação estatal perdeu força e legitimidade, até mesmo porque foi deixando de produzir resultados. Estado e governos ficaram acossados pela economia internacionalizada, que não podem controlar, e pelas demandas e pressões internas, que não podem refrear nem atender. Os governos governam pouco, às vezes, nem governam. Em termos gerais, passou a existir um expressivo déficit de autoridade política. Desapareceu também, por outro lado, a perspectiva da ruptura e da contestação efetiva.

A reviravolta, portanto, não se fez sem problemas. A aquisição de maior poder por parte dos indivíduos provoca, em alguma medida, um encolhimento do poder arbitrário dos Estados, dos governos e dos centros diretivos, o que certamente ajuda à democratização. Tal fato coincidiu com uma "desorganização" econômica e social ampliada que paralisou e dissolveu os grandes agregados (as classes) que serviam de referência material para a política. Declinaram, assim, as instituições políticas em sua totalidade. $\mathrm{O}$ processamento de demandas e a tomada de decisões foram então transferindo-se para indivíduos, grupos e movimentos auto-referidos.

Perdendo capacidade de exercer plenamente o monopólio do uso legítimo da força, o Estado passou a ter menos condições de atuar como promotor 
do "bem comum", de continuar a definir e executar políticas, tomar decisões gerais, garantir e proteger direitos. Aprofundou-se o divórcio entre Estado e sociedade, partidos e cidadãos, representantes e representados. Políticos, governantes e partidos afastaram-se dos fins superiores da política e enredaramse em seus meios, sejam eles a violência, a dissimulação, o orçamento ou a manipulação dos recursos de poder. Cresceu o risco de inoperância e de corrupção, diminuiu o impacto ético da política.

Uma crise ganhou corpo, como que a sugerir a "morte" da política tal como a conhecemos. Agredida e desajustada pelos novos termos da vida social, e fechando-se defensivamente em si mesma, a política converteu-se em um (sub) sistema que gera mais desordem e insegurança que respostas e soluções, inserindo-se num círculo de desgaste e deslegitimação. A perspectiva da eficiência, do ajuste, do controle técnico, da racionalidade instrumental, assim como a luta fria dos interesses ocuparam os mais recônditos nichos sociais e estacionaram no imaginário coletivo. A política deixou de ser, assim, o principal fator de composição social e de estabelecimento de equilíbrios e consensos. Tudo isso esvaziou de sentido as instituições políticas, banalizou e dessencializou suas regras e seus procedimentos, confundiu seus atores e, acima de tudo, modificou o da política. A política converteu-se em gestão de interesses, e os políticos em gestores, quase sempre impotentes para transformar as coisas ou dirigir as sociedades. Impõs-se outra idéia de governo: a de "cúpula" revestida de vontade e racionalidade próprias, vocacionada para administrar recursos, e que precisa se revelar o tempo todo sensata, equilibrada, responsável, avara, tecnicamente focada, e assim por diante. 
Ou seja, quanto menos política se passou a ter (quanto menos projetos coletivos e valores socialmente referidos), maior foi a sensação de que o poder político perdeu força, é oneroso demais e pouco necessário. Deslocou-se, assim, o peso das operações de transcendência política. Os incentivos passaram a ser para que cada um (grupo ou pessoa) encontre em si mesmo as fontes e os parâmetros de sua identidade e de sua satisfação, ou então, para que se transfira essa tarefa para técnicos e especialistas. Diminuiu a disposição societal para fazer com que os interesses particulares se traduzam em interesse coletivo.

O território da política foi assim ajustado, incluindo os diferentes protagonistas do universo partidário. Particularmente no caso dos partidos mais à esquerda, assistimos à sua progressiva conversão ao "sistema", ou seja, à redução de sua pujança reformista e de sua contundência. Tornaram-se mais preocupados em gerir recursos de poder e em maximizar seus próprios interesses eleitorais, deixando de agir para organizar novas hegemonias ou novos consensos e consentimentos. Em vez de se tornarem "fundadores de um novo Estado", como diria Gramsci, converteram-se em operadores passivos do mesmo Estado de sempre.

Passamos a viver no Brasil em um contexto de despolitização que tem duas faces. Uma expressa o afastamento das pessoas em relação à política e a desqualificação das práticas políticas. A outra expressa o surgimento, ainda difuso e errático, de politizações alternativas, que encontram nos indivíduos seu fulcro de ativação. Tais formas de politização repercutem as novas condições sociais e tentam driblar os impasses da política tradicional. Configuram uma tentativa embrionária de fundar um espaço de ação que responda a certos desafios do presente. São, no entanto, 
pouco contundentes, na medida em que permanecem "fora" da política instituída, seja porque são "expulsas" dela, seja porque se afastam deliberadamente dela. Sem modalidades alternativas de institucionalização, agindo muitas vezes de costas para o Estado, acabam por gerar mais "estado de natureza" e não conseguem impulsionar a composição de outro Estado, qual seja, de um Estado que tenha estruturas democráticas, leves e reflexivas, mas que funcione ativamente como parâmetro ético e político da sociedade.

\section{Encontros e desencontros}

A progressiva constituição desse ambiente de complexidade, fragmentação e crise explica o ponto com que desejo concluir. $\mathrm{O}$ pensamento democrático de esquerda que fez a redemocratização brasileira perdeu potência para continuar cumprindo as promessas das décadas de 1970 e 1980. Ainda que não tenha desaparecido, passou a enfrentar situações que o foram enfraquecendo e o estagnaram. Em seu momento inaugural, era um pensamento eminentemente político; o mundo com o qual passou a interagir é hostil à política, até mesmo porque está impregnado de colonização econômica do Estado, de demolição social, de corporativismo e pragmatismo.

Algumas expressões práticas daquele pensamento - como o PT, o PSDB, o PMDB - "chegaram ao poder”. Não se pôde, porém, celebrar a vitória das promessas da redemocratização. A passagem das oposições para o centro do poder político nacional fez-se em conjunto com a progressiva prevalência de uma idéia de política que não ajuda a democracia, não produz consensos, não fere a hegemonia e é refratária a perspectivas consistentes de coalizão democrática. Nas diferentes situações em que aque- 
les partidos assumiram "posição estatal” e governaram, pouco houve de significativo no que diz respeito à transformação do Estado; todos se submeteram ao Estado existente e nada produziram em termos de "reforma social" ou de alterações sustentáveis da correlação de forças.

O impacto que o amplo processo de transfiguração social teve sobre o pensamento político e particularmente sobre o pensamento e as práticas de esquerda é certamente um tema aberto. Muito terá de ser pesquisado e debatido antes que se chegue a conclusões categóricas. Falando, porém, em termos provisórios, creio ser possível sustentar algumas hipóteses de trabalho que apresentarei com o propósito de entender o que se passou com as famílias de esquerda que abraçaram a democracia política e se dedicaram, com alguma sistematicidade, a pensar a ação política.

O pensamento político interagiu com as tendências gerais, adaptando-se a elas. Tornou-se mais "institucional" que "social", mais "técnico" que "ideológico", mais "pragmático" que "cultural”, no sentido de que não se mostrou suficientemente virtuoso para articular essas faces inexoráveis da política. Tornouse, também, mais fragmentado e menos "orgânico”. Afastou-se dos temas quentes (os temas éticos e políticos, voltados para a construção de alternativas sociais) e entregou-se aos temas mais frios (os sistemas, as regras, a gestão). Passou a elaborar mais conceitos e estudos de caso, esmerou-se em metodologia, deslocando a teoria para uma posição menos relevante. Cientistas e formuladores políticos, nesse particular, acompanharam a conversão prévia ocorrida no próprio plano da política, que se especializou, se tecnificou e se fechou em si. 
Houve ganhos importantes em termos de lucidez e de oxigenação. Novas perspectivas foram incorporadas à bagagem cultural da esquerda. Ela própria passou a aceitar-se como força de governo. Dissolveram-se preconceitos e cristalizações ideológicas, uma lufada de realismo sacudiu diversas posições. Entretanto, o resultado geral não foi nada animador. Algo se perdeu em termos de antagonismo e de identidade alternativa. Os partidos democráticos e de esquerda democrática extenuaram-se como força de proposição crítica, ação antisistêmica e utopia.

A inflexão técnica do pensamento foi seguida por uma inflexão político-social. Esta, porém, não ganhou densidade suficiente para contrapor-se ao e se converter em efetivo pólo de disputa hegemônica. Foi travada por suas próprias características constitutivas.

Em primeiro lugar, ao propor-se como formulação aberta para o social, não soube completar-se com um discurso consistente sobre o institucional e sobre a governança em condições de modernidade radicalizada e periférica, com o que acabou por não se lançar no terreno "positivo" da reforma da política ou da reforma democrática do Estado.

Em segundo lugar, abrindo-se para o social, mas esvaziando-se de reflexão sistemática sobre o político e o institucional, tendeu a fixar-se num terreno eticista e moralizante, repleto de indignação e de preocupação com os interesses subalternos, mas despojado de mediações e articulações políticas. Ficou assim desarmada para o embate político em sentido amplo.

Em decorrência, tal inflexão não deu seqüência ao que se havia obtido, no correr dos anos de 1980, em termos de valorização da democracia política e de suas instituições. Acabou por ser, de certo modo, 
instrumentalizada tanto pela democracia liberal minimalista quanto pelos setores sociais refratários à democracia representativa. Não conseguiu projetarse como alternativa nem oferecer um caminho político para os movimentos sociais. A vertente técnica e a vertente político-social passaram, assim, a não se comunicar de maneira virtuosa. $\mathrm{O}$ foco de atenção de uma não freqüenta a agenda da outra, e vice-versa.

O resultado dessa evolução é que entramos no século XXI sem uma teoria com força suficiente para compreender politicamente o mundo em que vivemos. Há um vazio de sínteses, e isso, evidentemente, não apenas no plano teórico ${ }^{13}$. Ficamos com formas de ação política que se proclamam alternativas, mas que não têm alteridade e são pouco antagonistas.

É fora de dúvida que todo o pensamento político evoluiu com a redemocratização e com o que se seguiu a ela. Particularmente como "ciência política", os avanços foram expressivos, seja em termos de institucionalização, seja no que diz respeito ao acúmulo de conhecimentos sobre o Estado e o sistema político brasileiro. Nossos diagnósticos melhoraram, há uma produção expressiva de livros, artigos e pesquisas sobre os mais diferentes aspectos da vida nacional. O avanço é inegável, e não há como deixar de fazer seu elogio.

Mas o pensamento democrático de esquerda é mais que "ciência política". Ele precisa ter cientificidade, mas sua razão de ser está no plano crítico e positivo. Ele existe para contagiar a sociedade com um projeto de futuro, para converter diagnósticos em ação, para apresentar propostas para as diferentes questões da sociedade. Nisto, está deixando a desejar. Sua crise expressa seu silêncio teórico e sua fragilidade propositiva.

\footnotetext{
${ }^{13}$ Cf. Marco A. Nogueira (2001: 55-71).
} 
O quadro é terrivelmente complicado. Indivíduos, grupos e classes sociais, partidos e políticos, intelectuais e instituições educacionais, todos se encontram em busca de alternativas, deslizando estrutural e funcionalmente. Estamos perante o desafio de reinterpretar o capitalismo, de pensá-lo com categoriais novas e mediante a recomposição crítica das "velhas" categorias da sociologia clássica. Não ingressamos numa era de cegueira prática ou de negatividade absoluta, na qual política e sociedade deixaram de dialogar e na qual ficou impossível governar a economia e promover avanços sociais. A melhor hipótese, aqui, pode ser assim apresentada: tudo continua tão possível como antes, mas desde que se consiga agir e pensar de modo inovador. "A transformação real, histórica, deste mundo que habitamos traz consigo a transformação das linguagens da política"14.

Não se trata de "reforma política", expediente com o qual o debate corrente privilegia alguns ajustes tópicos que pouco agregam de potência à política e que mal conseguem sair do papel. E não saem do papel porque lhes falta precisamente a dimensão subjetiva, a presença de novos modos de pensar e fazer política. A reforma "da" política é algo bem mais vasto: repousa em uma complexa trama de sujeitos sociais, opções políticas e recursos institucionais. Não é questão autônoma ou revestida de precedência técnica, como se se tratasse de estabelecer, em abstrato, os mecanismos institucionais, as regras e as práticas do bom governo. Sua meta é construir procedimentos e instituições capazes de aproximar Estado e cidadãos, organizações estatais e organizações societais, política e Estado. Deste ponto de vista, o programa da democracia progressiva continua aberto.

\footnotetext{
${ }^{14}$ Negri (2006: 242).
} 
Poder-se-ia dizer que seria o caso de voltar aos "anos de ouro" da luta contra a ditadura, quando se tinha um adversário claro a combater, quando o programa intelectual se mostrava nítido à frente de todos, quando a democracia progressiva era uma promessa factível e suficientemente convincente para animar pessoas e instituições. Contudo, o mundo mudou, e não há como retroceder. Sob novas determinações, há que se pensar diferente. O próprio modo de ser da política, suas linguagens e seus sujeitos são de outra qualidade e exigem novos empreendimentos intelectuais.

A questão pode ser assim apresentada: "Como pensar uma política anticapitalista na atual conjuntura, quando o capitalismo histórico parece ter entrado em uma fase de caos sistêmico e turbulência global? Como pensar a política, uma vez que se objetivaram novas modalidades históricas de existência do sujeito político antagonista?"15. Em termos mais focalizados: como conceber a articulação de Estado e sociedade e a reposição do valor da política nas condições atuais de modernização radicalizada e periférica?

Não se trata de lamentar o que não pôde ser feito ou o que se perdeu e não existe mais. Precisamos manter-nos no olho do furacão, interpelando o mundo e tentando descobrir as chaves de acesso para o futuro. Os avanços obtidos nas últimas décadas têm potência para que superemos o quadro atual. Em que pesem as dificuldades, há uma malha de movimentos e organizações agindo a favor do pensamento crítico. E instituições como o Cedec - que fizeram e pensaram a redemocratização e continuam a pensar e a fazer a democratização - são um farol de que não se pode abdicar. Que tenham longa vida.

\footnotetext{
${ }^{15}$ Negri (2006: 239).
} 


\section{Referência bibliográfica deste depoimento}

BECK, Ulrich. 2001. La società del rischio. Verso una seconda modernità. Roma: Carocci Editore.

. 2003. Liberdade ou capitalismo. Ulrich Beck conversa com Johannes Willms. São Paulo: Unesp.

BRANDÃO, Gildo Marçal. 1997. A esquerda positiva. As duas almas do Partido Comunista - 1920-1964. São Paulo, Hucitec.

COUTINHO, Carlos Nelson. 1979. "A democracia como valor universal". Encontros com a civilização brasileira.

GARCIA, Marco Aurélio (Org.). 1986. As esquerdas e a democracia. Rio de Janeiro: Paz e Terra/Cedec.

KONDER, Leandro. 1980. A democracia e os comunistas no Brasil. Rio de Janeiro: Graal.

NEGRI, Antonio. 2006. Movimenti nell'Impero. Passaggi e paesaggi. Milão: Raffaello Cortina Editore.

NOGUEIRA, Marco A. 2001. "A síntese como problema”. Lua Nova, São Paulo, v. 54, p. 55-71.

. 2005. Um Estado para a sociedade civil. Temas éticos e políticos da gestão democrática. 2. ed. São Paulo: Cortez.

2007. "Bem mais que pós-moderno: poder, sociedade civil e democracia na modernidade periférica radicalizada”. Ciências Sociais Unisinos, vol. 43, n. 1, janeiro/abril, p. 46-56.

PALERM0, Vicente. 2006. “Quitame de allá esas papeleras!”. Revista Eletrônica Gramsci e o Brasil, fevereiro. Disponível em: http:/ /www.acessa.com/ gramsci $/$ ? page $=$ visualizar\&id $=27$.

PCB. Unidade, renovação, democracia. Resoluções do Encontro Estadual de São Paulo pela Legalidade do PCB. São Paulo: Caetés, 1982.

REIS FILHO, Daniel Aarão. 1985. Imagens da Revolução. Rio de Janeiro: Marco Zero.

REVELLI, Marco. 2003. La politica perduta. Turim: Einaudi. p. 83.

SENNETT, Richard. 2006. La cultura del nuovo capitalismo. Bolonha: Il Mulino. p. 36 .

TOGLIATTI, Palmiro. 1947. "Diritti e rapporti sociali”. In: Discorsi alla Constituente. Roma: Riuniti. p. 36.

. (1958) 1966. O caminho italiano para o socialismo. Rio de Janeiro: Civilização Brasileira, p. 116.

WEFFORT, Francisco. 1984. Por que democracia? São Paulo: Brasiliense 


\section{Marilena Chauí}

é professora do Departamento de Filosofia da FFLCH-USP

\section{Marco Aurélio Nogueira}

é professor de Teoria Política da Faculdade de Ciências e Letras da Unesp/Araraquara 


\section{PARTE II: SEMINÁRIOS CEDEC 30 ANOS}

\section{( ) \\ O PENSAMENTO POLÍTICO E A REDEMOCRATIZAÇÃO dO BRASIL}

Marilena Chauí e Marco Aurélio Nogueira, os expositores deste primeiro seminário em comemoração dos trinta anos do Cedec, discutem a origem da instituição à luz dos debates acadêmicos, políticos e culturais, ocorridos no Brasil e no exterior naquele período, sobre os futuros da democracia e do socialismo.

Palavras-chave: Democracia; Socialismo; Brasil; Cedec.

\section{POLITICAL THOUGHT AND THE BRAZILIAN RETURN TO} DEMOCRACY

Marilena Chaui and Marco Aurélio Nogueira, the speakers of the first seminar on behalf of Cedec's Thirty Years, discuss the origins of Cedec in the light of the academic, political and cultural debates, which took place in Brazil and abroad at that time, on the future of democracy and socialism.

Keywords: Democracy; Socialism; Brazil; Cedec. 